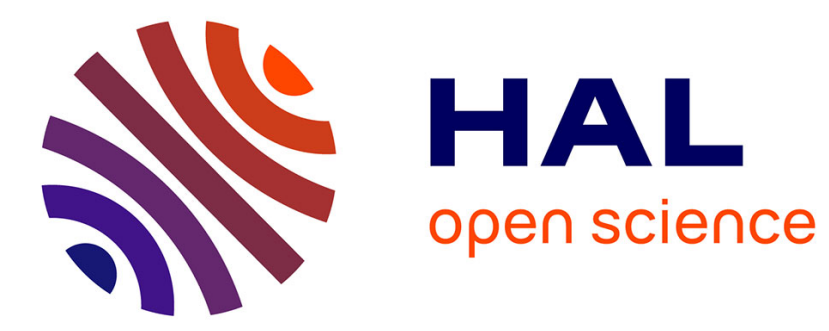

\title{
Potentialities of dark fermentation effluent as substrates for microalgae growth: A review
}

\author{
Violette Turon, Eric Trably, Eric Fouilland, Jean-Philippe Steyer
}

\section{To cite this version:}

Violette Turon, Eric Trably, Eric Fouilland, Jean-Philippe Steyer. Potentialities of dark fermentation effluent as substrates for microalgae growth: A review. Process Biochemistry, 2016, 51 (11), pp.18431854. 10.1016/j.procbio.2016.03.018 . hal-01608537

\section{HAL Id: hal-01608537 \\ https://hal.science/hal-01608537}

Submitted on 27 May 2020

HAL is a multi-disciplinary open access archive for the deposit and dissemination of scientific research documents, whether they are published or not. The documents may come from teaching and research institutions in France or abroad, or from public or private research centers.
L'archive ouverte pluridisciplinaire HAL, est destinée au dépôt et à la diffusion de documents scientifiques de niveau recherche, publiés ou non, émanant des établissements d'enseignement et de recherche français ou étrangers, des laboratoires publics ou privés. 


\section{Accepted Manuscript}

Title: Potentialities of dark fermentation effluent as substrates for microalgae growth: A review

Author: V. Turon E. Trably E. Fouilland J-P. Steyer

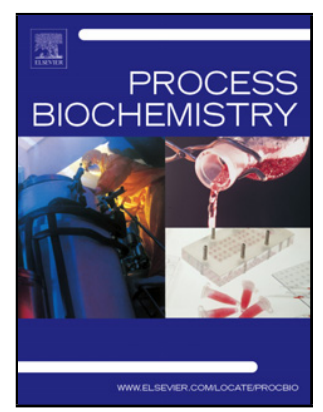

PII: S1359-5113(16)30068-X

DOI: http://dx.doi.org/doi:10.1016/j.procbio.2016.03.018

Reference: PRBI 10650

To appear in: Process Biochemistry

Received date: 31-10-2015

Revised date: 4-3-2016

Accepted date: 31-3-2016

Please cite this article as: Turon V, Trably E, Fouilland E, Steyer J-P.Potentialities of dark fermentation effluent as substrates for microalgae growth: A review.Process Biochemistry http://dx.doi.org/10.1016/j.procbio.2016.03.018

This is a PDF file of an unedited manuscript that has been accepted for publication. As a service to our customers we are providing this early version of the manuscript. The manuscript will undergo copyediting, typesetting, and review of the resulting proof before it is published in its final form. Please note that during the production process errors may be discovered which could affect the content, and all legal disclaimers that apply to the journal pertain. 


\section{Potentialities of dark fermentation effluent as substrates for microalgae} growth: A review

V. TURON ${ }^{\mathrm{a}}$, E. TRABLY ${ }^{\mathrm{a}^{*}}$ E. FOUILLAND ${ }^{\mathrm{b}}$ and J-P. STEYER ${ }^{\mathrm{a}}$

${ }^{a}$ INRA, UR0050 Laboratoire de Biotechnologie de l'Environnement, F-11100 Narbonne, France.

${ }^{b}$ Marine Biodiversity, Exploitation and Conservation -UMR 9190 MARBEC-CNRS, UM, IFREMER, IRD, Station Marine, Université de Montpellier, 2 Rue des Chantiers, 34200 Sète, France.

*Corresponding author: eric.trably@supagro.inra.fr 


\section{Highlights}

- Coupling dark fermentation and microalgae production in a biorefinery concept.

- The broad range of fermentation metabolites production is explained.

- The use of fermentation metabolites as substrates for microalgae is discussed.

- The challenges and prospects of this promising coupling are outlined. 


\begin{abstract}
In recent years, coupling bacterial dark fermentation (DF) and heterotrophic cultivation of microalgae (HCM) has been pointed out as a promising sustainable approach for producing both gaseous and liquid biofuels. Complex organic waste and effluents that are not susceptible to be directly degraded by microalgae are first converted into volatile fatty acids (VFAs) and hydrogen by DF.

In this work, the feasibility of using DF effluents to sustain has been thoroughly reviewed and evaluated. Promising perspectives in terms of microalgae biomass and lipids production are proposed and can be extended as guidelines to promote HCM whatever the organic waste used. Abiotic and biotic factors from DF effluents that promote or inhibit microalgae growth are discussed as well as the use of unsterile DF effluents. Overall, the microalgae growth is favored on effluents containing high acetate concentration $\left(>3 \mathrm{~g} . \mathrm{L}^{-1}\right)$, with a high acetate:butyrate ratio $(>2.5)$, and when $\mathrm{pH}$ is strictly controlled. At a low acetate:butyrate ratio $(<1)$ and/or high total metabolites concentrations $(>10$ g.L ${ }^{1}$ ), a low substrate:microalgae ratio and the presence of light appear to enhance microalgae growth.

Butyrate content appears to be a key factor when coupling DF/HCM since high butyrate concentration inhibits the microalgae growth.
\end{abstract}

Keywords:Acidogenesis; Biohydrogen; Dark fermentation; Heterotrophy; Microalgae 


\section{Introduction}

Nowadays, volatile fatty acids (VFAs) and hydrogen are both produced through chemical routes relying directly or indirectly on fossil fuels which precludes their use for environment friendly applications as fuels or for electricity generation [1,2]. Energy and chemicals production not relying on traditional oil refinery that emits high amounts of greenhouse gases is one of the most crucial challenges of the $21^{\text {th }}$ century. Another main challenge is to reduce the pollution unleashed by the constant increase of human waste. Environmental biorefineries, as sustainable platforms "producing bio-based products (food, feed and chemicals) and energy (fuels, heat and electricity) from biomass" [3], may constitute a potential solution for addressing these issues. The combination of both VFAs and hydrogen production in dark fermentation (DF) processes treating waste is a good example of the environmental biorefinery concept where energy and biomolecules are produced concomitantly with waste treatment. Indeed, hydrogen is considered as one of the most promising solution of replacement of fossils fuels since it is a very high energy carrier $\left(122 \mathrm{~kJ}_{\mathrm{g}} \mathrm{g}^{-1}\right)$ and its oxidative combustion produces only water vapor as end-product [4]. Furthermore, hydrogen could be used as a sustainable source of electricity for wide uses such as transportation through fuel cells technologies [2]. In addition, VFAs can be used as substrates by various microorganisms such as oleaginous yeasts or microalgae [1] for the production of chemicals (bioplastics) and energy (biodiesel and electricity).

In recent years, coupling bacterial DF, which produces hydrogen and VFAs, and heterotrophic cultivation of microalgae, which produces lipids, has been suggested as being a very promising sustainable approach for producing gaseous and liquid biofuels (Figure 1) [5]. DF is a simple process that can convert a wide range of solid waste and effluents into hydrogen [6]. During DF, anaerobic bacteria break down complex carbon compounds from the organic matter contained in waste (e.g., food waste or agricultural waste) and wastewater (e.g., wastewater from agriculture, paper or sugar industries) into simple organic acids [1]. Acetic and butyric acids are the two main end-products of DF and can be further used as low cost carbon sources to sustain the growth of heterotrophic microalgae [7]. The main advantage of DF is that organic carbon compounds from complex waste that are not directly available to microalgae degradation are simplified into low molecular weight VFAs [8]. Acidogenic fermentation (AF) is an alternative version of DF where hydrogen is converted into acetate to maximize VFAs production with no $\mathrm{H}_{2}$. AF effluents can also be used to sustain microalgae growth [9]. Moreover, thanks to nitrogen $(\mathrm{N})$ and phosphorus $(\mathrm{P})$ mineralization into ammonium and orthophosphate during DF [10], effluents may also contain sufficient amounts of $\mathrm{N}$ and $\mathrm{P}$ that are required to sustain the heterotrophic growth of microalgae. Recently, some studies investigated the feasibility of using DF or AF effluents, composed mainly of acetate and butyrate, to sustain microalgae growth and showed very promising perspectives in terms of production of microalgae biomass and lipids [7,9,11-18]. To our knowledge, no economic assessment has been published concerning the production of algal-lipid production when microalgae are heterotrophically growing on 
dark fermentation effluents. However, some studies estimated the cost of biodiesel based on lipid production by yeasts (containing $30 \%$ of lipids), supplemented with fermentation effluents, between 0.71 and $2.23 \$ / \mathrm{L}$ and should be economically competitive with the current diesel [19,20]. Further studies are required to assess the economic viability of the actual coupling of dark fermentation with algal lipid production. Such studies should consider not only heterotrophic algal growth but also mixotrophic growth, as light is an extra cost but allows the production of highly valuable molecules (e.g. pigments) as well.

The main objective of this work is to thoroughly review and discuss the abiotic (composition of the effluents, substrate:microalgae ( $\mathrm{S} / \mathrm{X}$ ) ratio, dark or light conditions, $\mathrm{pH}$ and temperature) and biotic parameters (fermentation bacteria and microalgae species) that influence the microalgae growth on synthetic and raw fermentation effluents. First, this review briefly describes the fermentation principles and processes in order to assess the impact of DF and AF effluents variability in terms of types and concentrations of metabolites and bacterial diversity (section 2). Indeed, fermentation effluents consist of various low-cost carbon sources, VFAs and alcohols, and the subsequent microalgae growth on these compounds depends mostly on metabolites composition and concentrations as reported with synthetic (section 3) and raw DF effluent (section 4). The impact of the presence of fermentative bacteria on microalgae growth when using unsterile fermentation effluents is also illustrated and discussed (section 4). Finally, the main technical and scientific challenges to obtain a successful coupling between DF and microalgae growth are discussed.

\section{Brief overview of dark and acidogenic fermentation processes}

\subsection{Principles of DF and AF and bacterial diversity involved}

Dark fermentation (DF) is part of the full anaerobic digestion (AD) process, ending with VFAs and hydrogen production carried out by anaerobic fermentative bacteria (Figure 2). In acidogenic fermentation (AF), which targets VFAs production, $\mathrm{H}_{2}$ is exhausted by favoring acetogenesis, the third step of $\mathrm{AD}$, to maximize acetate production [21].

Hydrogen and VFAs production by DF and AF has been intensively studied using either mixed cultures from soils or anaerobic digesters or co-cultures (two selected species) or monospecific cultures of hydrogen-producing species $[1,22]$. When using waste streams, mixed cultures allow the use of a broad range of unsterile substrates and lower the overall cost of the process since aseptic conditions are not required [23]. Moreover, the diversity of the microbial community can stabilize the degradation of waste (several species can perform the same task according to their affinity with the substrate) [24]. The main disadvantage of using mixed culture is the presence of non- $\mathrm{H}_{2}$-producing species which use the substrate or waste for other pathways [25]. 
In mixed cultures, the main hydrogen-producing fermentation pathways during DF are the acetate pathway and the butyrate pathway. The theoretical hydrogen yields of the acetate and butyrate pathways are 4 and 2 moles of hydrogen per mole of glucose consumed, respectively (Eq 1 and Eq 2).

$$
\begin{array}{ll}
\mathrm{C}_{6} \mathrm{H}_{12} \mathrm{O}_{6}+2 \mathrm{H}_{2} \mathrm{O} \rightarrow 2 \mathrm{CH}_{3} \mathrm{COOH}+2 \mathrm{CO}_{2}+4 \mathrm{H}_{2} & \text { Equation 1 } \\
\mathrm{C}_{6} \mathrm{H}_{12} \mathrm{O}_{6} \rightarrow \mathrm{CH}_{3} \mathrm{CH}_{2} \mathrm{CH}_{2} \mathrm{COOH}+2 \mathrm{CO}_{2}+2 \mathrm{H}_{2} & \text { Equation 2 }
\end{array}
$$

Hydrogen is produced in both pathways and the molar ratio of acetate:butyrate depends on many operational parameters (e.g. bacterial species involved, $\mathrm{pH}$, hydraulic retention time - HRT) [26,27]. Hawkes et al. (2007) suggested the following equation (Equation 3) to describe hydrogen production in mixed cultures with an average acetate:butyrate molar ratio of 0.66 :

$$
4 \mathrm{C}_{6} \mathrm{H}_{12} \mathrm{O}_{6}+2 \mathrm{H}_{2} \mathrm{O} \rightarrow 3 \mathrm{CH}_{3} \mathrm{CH}_{2} \mathrm{CH}_{2} \mathrm{COOH}+2 \mathrm{CH}_{3} \mathrm{COOH}+2 \mathrm{CO}_{2}+10 \mathrm{H}_{2} \quad \text { Equation } 3
$$

According to Equation 3, the theoretical hydrogen yield in mixed cultures should be 2.5 mol of hydrogen per mol of glucose consumed. Clostridium sp, a spore-forming strict anaerobic bacteria, are usually the main $\mathrm{H}_{2}$-producing bacteria in mixed cultures [23].

Practically, the $\mathrm{H}_{2}$ experimental yields observed in mixed cultures are usually lower than the theoretical yields, ranging between 0.4 to $3 \mathrm{~mol} \mathrm{H}_{2} / \mathrm{mol}$ of glucose consumed [23,25]. Such lower yields result from the presence of competitive non $\mathrm{H}_{2}$-generating pathways or other metabolic pathways that directly consume hydrogen $[2,4]$. Overall, the main hydrogen consumers found in DF bioreactors are methanogenic archaea. Sulfate and nitrate reducers also consume $\mathrm{H}_{2}$ to produce $\mathrm{H}_{2} \mathrm{~S}$ and $\mathrm{NH}_{3}$, respectively. Clostridium sp. can use different substrate or hydrogen, as an electron donor, to generate propionate, ethanol, lactate, valerate, formate, acetone or butanol when $\mathrm{pH}$ is low or at high concentration of VFAs [21]. For instance, homoacetogenic bacteria, such as Clostridium aceticum, can convert $\mathrm{H}_{2}$ and $\mathrm{CO}_{2}$ into acetate. This step is favorable to VFAs production and is therefore very important in AF processes. In addition, some other species, such as lactic bacteria, Lactobacillus sp. or Sporolactobacillus sp. outcompete hydrogen producers for the substrate.

\subsection{DF and AF operating conditions}

By definition, a sustainable feedstock for DF and AF should be abundant, readily available, cheap and highly biodegradable [4]. Crop residues, animal manure, food waste, sludge from anaerobic treatment plants, effluents from sugar or paper industries are among the most studied feedstocks to sustain hydrogen production $[1,4]$. According to the waste composition and its content in carbohydrates, protein and fats, a broad range of $\mathrm{H}_{2}$ and VFAs production can be achieved (Table 1). Indeed, carbohydrate-rich waste achieve higher $\mathrm{H}_{2}$ production since carbohydrates have been identified as the main component source in waste correlating with hydrogen production $[25,28]$. Simple sugars such as glucose and sucrose (glucose + fructose) are routinely used as model substrates to study and characterize hydrogen production with mixed cultures [29,30]. 
Physical pretreatments (heat, ultraviolet irradiation, freeze) and chemical pretreatments (incubation at very acidic or alkali $\mathrm{pH}$ ) of the bacterial inoculum have been used to induce cell lysis of nonsporulating non- $\mathrm{H}_{2}$-producing or $\mathrm{H}_{2}$-consuming bacteria. Clostridium species survive the pretreatment thanks to ability to sporulate. In the DF reactor, the operational conditions are favorable enough to allow germination of spores of Clostridium species. Usually, heat shock treatment gives the best results [23].

Under batch, semi-continuous and continuous modes, hydrogen production can also be modulated by the substrate concentration [31]. The optimal glucose concentration is around $10 \mathrm{~g} . \mathrm{L}^{-1}$, which does not inhibit $\mathrm{H}_{2}$-producers but inhibits methanogens through $\mathrm{pH}$ variation [31]. Low initial glucose concentration also prevents the accumulation of end-products (VFAs) which can lead to sporulation of Clostridium sp. or a shift to alcohol production reducing the $\mathrm{H}_{2}$ yield, also called solventogenesis $[4,26]$. When using organic waste, high organic loading rate (OLR) can lead to VFAs accumulation and decrease hydrogen production [32]. Moreover, OLR and related hydraulic retention time (HRT) are two key parameters influencing the bacterial community structure, and thus the fermentation performances when reactors are operated in continuous mode [26]. A short HRT $(\leq 6 \mathrm{~h})$ favors the fast growing $\mathrm{H}_{2}$-producing Clostridium sp. and tends to wash out the slow growing methanogenic bacteria [2]. HRT in AF are longer than for DF, between $6 \mathrm{~h}$ to 4 days, since $\mathrm{H}_{2}$ has to be converted into VFAs. Shorter HRT tend to favor butyrate production over propionate production [1].

The $\mathrm{pH}$ is a critical operational parameter in DF since its variation can affect the hydrogenase activity, the metabolic pathways and the microbial community structure [33]. A pH drop due to the production of VFAs is known to lead to a shift in metabolism, from $\mathrm{H}_{2}$ production to solventogenesis [26]. As an illustration, the butyrate pathway is predominant in Clostridium tyrobutyricum at $\mathrm{pH} 6$ while, at $\mathrm{pH} 5$, a metabolic shift from butyrate fermentation to lactate and acetate fermentation can occur [34]. In AF processes, $\mathrm{pH}$ can be adjusted to target specifically the VFAs production. For instance, $\mathrm{pH} 6-6.5$ will promote Clostridium sp. and acetate, butyrate production whereas propionate production can be enhanced by the presence of Propiobacterium sp. which growth is promoted at $\mathrm{pH} 8$ [1].

The DF process has also been operated over a broad range of temperatures (Table 1), i.e. mesophilic $\left(35-37^{\circ} \mathrm{C}\right)$, thermophilic $\left(50-70{ }^{\circ} \mathrm{C}\right)$ and hyperthermophilic $\left(>80^{\circ} \mathrm{C}\right)$ [2]. Temperature can cause a shift in the bacterial community leading in subsequent variations in metabolic end-products distribution. Generally, acetate is the main metabolite present when processes are performed at thermophilic or hyperthermophilic temperatures whereas butyrate is dominant in processes performed at mesophilic temperature [2]. Nevertheless, counterexamples exist since hydrogen metabolic pathways depend also on the structure of the microbial community, the $\mathrm{pH}$, the type of feedstocks and the organic loading rate [2]. Temperature is not as critical as $\mathrm{pH}$ and is usually set around $35-37^{\circ} \mathrm{C}$ to avoid stability related issues due to thermophilic temperatures. 


\subsection{Characteristics of fermentation effluents}

Optimally, a large fraction (50-80\%) of the biodegradable COD from the feedstock is transformed into soluble metabolites in DF (and 100\% in AF) [35]. Theoretically, 66.7\% and $83 \%$ of the COD from glucose is converted into acetate through the acetate-pathway (Equation 1) and into butyrate through the butyrate-pathway (Equation 2), respectively. However, due to the large variability in organic matter composition, microbial consortium origins and operational parameters of DF and AF processes, no typical composition of metabolites can be provided (Table 1). Acetate and butyrate concentrations, along with the acetate:butyrate ratio ranging between 0.4 and 6.7, can vary at a great extent. According to the acetate and butyrate pathways (Equations 1 and 2, respectively), theoretical VFAs production from $10 \mathrm{~g} . \mathrm{L}^{-1}$ of glucose can reach $6.7 \mathrm{~g} . \mathrm{L}^{-1}$ of acetate and $4.9 \mathrm{~g} . \mathrm{L}^{-1}$ of butyrate.

\section{Growth of microalgae on synthetic effluents: abiotic influence}

The microalgae growth on multiple organic substrates, such as mixtures of acetate and butyrate from $\mathrm{DF} / \mathrm{AF}$ effluents, is driven by the composition and the proportion of each substrates, the total organic substrate concentration and the ratio $(\mathrm{S} / \mathrm{X})$ between the substrate concentration and the initial biomass concentration [36,37]. All these parameters are linked together. Understanding their individual influence on microalgae growth as well as the interactions between them is crucial to further promote the microalgae growth on fermentation effluents. In addition, the culture conditions in mixotrophy or heterotrophy (presence of light or not), $\mathrm{pH}$ and temperature controls, have tremendous effects on microalgae growth. In this section, unravelling the effect on microalgae growth of the proportion of each substrate, their initial concentration, the $\mathrm{S} / \mathrm{X}$ ratio, the presence of light, $\mathrm{pH}$ and temperature was attempted with synthetic effluent to better understand the results observed during growth on raw effluents (section 4). Assimilation and metabolism associated with heterotrophic (darkness, with organic carbon compounds as sole substrate) and mixotrophic (in presence of light, organic and inorganic carbon compounds) conditions of microalgae growth on acetate and butyrate are presented first. Comparisons with results obtained during growth of oleaginous yeast such as Yarrowia lipolytica and Cryptococcus sp. on DF or AF effluents are also included.

\subsection{Assimilation of fermentation products by microalgae and metabolisms involved}

Under both heterotrophic and mixotrophic conditions, acetate is actively assimilated by eukaryotic microorganisms through a monocarboxylic/proton transport protein [38]. Then, acetate is carried into the cellular glyoxysome where it is transformed into acetyl-CoA, a central precursor metabolite, by the acetyl-CoA synthetase. Acetyl-CoA participates to the glyoxylate cycle, a variant of the Krebs cycle allowing the synthesis of precursor metabolites from two-carbon substrates. The two enzymes specific of the glyoxylate cycle are the isocitrate lyase and the malate synthetase which allow the formation of four-carbon metabolites from acetyl-CoA. 
Unlike acetate, butyrate assimilation by microalgae has not been extensively studied. As for acetate, butyrate is probably actively transported into the cell via a monocarboxylic/proton transporter and further metabolized in the glyoxysome [38,39]. In the glyoxysome, butyrate might be activated into acetyl-CoA through $\beta$-oxidation and then enter into the glyoxylate cycle [39]. Whereas high acetate concentration (up to 20 g.L. $\mathrm{L}^{-1}$ [40]) have been used to sustain microalgae growth, butyrate concentration as low as $0.5 \mathrm{~g} . \mathrm{L}^{-1}$ has been shown to inhibit microalgae growth $[41,42]$. Butyrate inhibition on microalgae growth might be the result of an acidification of the cytosol after assimilation of the undissociated form of butyrate (butyric acid) [43].

Assimilation of the other fermentation metabolites, such as propionate, lactate and ethanol, seem to be highly species-specific (Table 2). Since most of the studies on heterotrophic and mixotrophic microalgae growth have been carried out using glucose or acetate as carbon sources [38], the consequence of the complex composition in organic carbon of DF and AF effluents is still not well known on microalgal heterotrophic growth.

When microalgae are grown on organic compounds under light conditions, the understanding of the interactions existing between heterotrophic and autotrophic metabolisms, i.e. the proportion of biomass produced from $\mathrm{CO}_{2}$ or from organic carbon, during mixotrophic growth of microalgae is still a challenge $[44,45]$. It has been generally observed that biomass yield and growth rate are higher under mixotrophic conditions than autotrophic or heterotrophic conditions [46]. However, no clear and mechanistic explanation has been provided to this statement, mainly because of the difficulty to distinguish the contribution of autotrophic and heterotrophic metabolisms involved in algal growth and biomass anabolism. The direct impact of the presence light on microalgae growth on mixtures of VFAs is discussed in Section 3.4.

\subsection{Influence of acetate:butyrate ratios on microalgae growth}

Until recently, organic carbon substrates have only been studied as single substrate to sustain microalgae growth in heterotrophic conditions. Nevertheless, in carbon-rich wastewaters or industrial effluents, several carbon sources are usually available to support the microalgae growth [46]. DF and AF effluents are composed of various proportions of VFAs and other organic metabolites (section 2).

Only few studies clearly investigated the impact of VFAs ratio on heterotrophic microalgae growth at a fixed initial concentration of total VFAs (i.e. different ratios but similar initial VFAs concentration) [11,42,47]. According to Fei et al. (2014) and Turon et al. (2015a), a high acetate concentration was favorable for Chlorella protothecoides and Chlorella sorokiniana growth with regards to the butyrate and propionate. Zhang (2012) showed that whatever the acetate:butyrate ratio (i.e. between 0.25 and 4 in $\mathrm{g} \cdot \mathrm{g}^{-1}$ ) similar biomass yields were achieved with Crypthecodinium cohnii. Nevertheless, the medium used to sustain $C$. cohnii growth was supplemented with yeast extract, 2 g. $\mathrm{L}^{-1}$, which contains unknown forms of organic carbon and therefore might have contributed to microalgae growth. 
When using a VFAs mixture, the biomass yields of $C$ protothecoides (g biomass per g total VFAs) decreased from 0.33 to 0.16 along with the decrease in the initial proportion of acetate in the mixture, likely due to an incomplete exhaustion of butyrate and/or propionate [11]. The lipids content of the microalgae biomass also dropped from $48.5 \%$ to $35 \%$ with the reduction of the acetate content in the substrate mixture. According to Turon et al. (2015a), the biomass yields measured on either acetate or butyrate were very similar ( 0.38 and $0.48 \mathrm{~g}$ of carbon from biomass per $\mathrm{g}$ of carbon, respectively). The slow growth rate during butyrate uptake $\left(0.2 \mathrm{~d}^{-1}\right)$ compared to the fast one during acetate uptake $\left(2 \mathrm{~d}^{-1}\right)$ for A. protothecoides [42] could explain the incomplete butyrate exhaustion observed by Fei et al. (2014). Fei et al. (2014) mentioned that butyrate and propionate uptakes were accelerated after acetate exhaustion. This observation suggests that the presence of acetate unfavors butyrate and propionate uptakes. A diauxic phenomenon was evidenced by Turon et al. (2015a) during the heterotrophic growth of A. protothecoides[42]. Indeed, during microbial growth on multiple carbon substrates, either simultaneous uptake of different substrates or sequential uptakes, also called diauxic effect, are possible and are modulated according to the substrates ratio [36]. Diauxic phenomena are usual when one of the substrate present in the medium is preferred over another, for example when the growth rate during the uptake of one of the substrate is higher than with the other substrate [48]. Enzymatic repression is often the cause of a diauxic effect, e.g., repression of the synthesis of the transporter protein [36]. Even though such diauxic effect resulted in an inhibition of the butyrate assimilation in presence of acetate, the presence of acetate had also a positive effect on the growth of $A$.

protothecoides on butyrate since the acetate uptake lead to an increase in biomass and, consequently, the apparent butyrate uptake was faster than in absence of acetate [42]. Nevertheless, the specific butyrate uptake rate, when normalized to the biomass concentration, remained very similar.

\subsection{Influence of total VFAs concentration and S/X ratio on the microalgae growth}

As previously pointed out by Bumbak et al (2011), high organic substrate concentration (e.g., glucose, acetate) can be inhibitory to the microalgae growth [49]. Under both heterotrophic and mixotrophic growth conditions, the biomass yields of Chlorella protothecoides and Chlamydomonas reinhardtii were inhibited when the total VFAs concentration was increased above 2 g.L $\mathrm{L}^{-1}[11,16]$. However, the latter experiments were carried out with no control of the $\mathrm{pH}$ during the culture and, at such high VFAs concentration and even though the initial $\mathrm{pH}$ was close to neutrality, a $\mathrm{pH}$ increase likely occurred due to the uptake of the weak acids during the growth of microalgae. Such $\mathrm{pH}$ increase might have been the cause of the decrease in microalgae biomass yield.

At similar initial microalgae concentration (X), the increase in the concentration of VFAs (S) results in a higher initial S/X ratio. In order to reduce the time to reach complete VFAs degradation and reduce VFAs inhibition, the initial $\mathrm{S} / \mathrm{X}$ ratio could be lowered by either diluting the medium or increasing the initial microalgae load [14]. When butyrate is provided as substrate and under light culture conditions, the reduction of the $\mathrm{S} / \mathrm{X}$ ratio from 4.8 to 1.1 resulted in an increase in the final biomass production by 
$50 \%$ and complete butyrate exhaustion, during the growth of Chlorella vulgaris [14]. Nevertheless, the composition of VFAs has still to be taken into account when discussing the results. It could be expected that the $\mathrm{S} / \mathrm{X}$ ratio has to be set according to the acetate:butyrate ratio. For instance, with a high acetate:butyrate:propionate ratio of 8:1:1 and a high S/X of 20, Chlamydomonas reinhardtii could grow without inhibition at 2 g.L.-1 of VFAs [16]. To avoid growth inhibition by high total VFAs concentration and to reach high-density cultures, operational processes such as fed-batch cultivation (sequential addition of the substrate) and perfusion techniques (particular continuous culture mode where the cells are physically retained in the culture) could be used [49]. Indeed, under these two culture modes, the S/X can be adjusted so the VFAs concentration remains under inhibitory concentration.

\subsection{Mixotrophic mode of assimilation: the effects of light and $\mathrm{CO}_{2}$}

During mixotrophic growth on VFAs, microalgae are expected to assimilate $\mathrm{CO}_{2}$ and thus to generate autotropically biomass and to accelerate the apparent uptake of VFAs in heterotrophic cells (subsection 3.1).Therefore, the autotrophic growth could be considered as another way to lower the S/X ratio. The results obtained by Liu et al (2012) evidenced that both butyrate and inorganic carbon uptakes occurred simultaneously during a mixotrophic growth of Chlorella vulgaris. Indeed, only simultaneous assimilation of both compounds can explain the biomass yield observed on butyrate that were higher than 1, i.e. $2.1 \mathrm{~g}^{\mathrm{g}} \mathrm{g}^{-1}$ [14]. This observation highlights the need to discuss with caution the values of biomass yields obtained at the end of a mixotrophic growth. The authors pointed out that inorganic carbon was a preferred substrate when compared to butyrate. Indeed, C. vulgaris growth rate on a mixture of butyrate and bicarbonate $\left(\mathrm{HCO}_{3}{ }^{-}\right)$, ranging from 0.52 to $0.63 \mathrm{~d}^{-1}$, was significantly lower than the one observed during autotrophic growth on $\mathrm{HCO}_{3}{ }^{-}$as single substrate, $0.97 \mathrm{~d}^{-1}$ [14]. In addition, the butyrate: $\mathrm{HCO}_{3}{ }^{-}$ratio appeared to be important in order to avoid only autotrophic growth with no butyrate assimilation [14].

High light intensities (> $300 \mu \mathrm{mol}$ photons. $\mathrm{m}^{2} . \mathrm{s}^{-1}$ for $C$ vulgaris) also need to be carefully managed to avoid photo-inhibition or a complete autotrophic metabolism [15]. This parameter is probably species dependent, at least for the effect of light intensity on mixotrophic growth, and need to date further investigations. The interactions between heterotrophic and autotrophic metabolisms during mixotrophic growth of Chlorella sorokiniana on a mixture of acetate and butyrate have been recently studied [50]. It was shown that mixotrophic biomass production relied mostly on heterotrophic metabolism (61\%) during acetate uptake whereas it relied mostly on autotrophic metabolism (62\%) during butyrate uptake. Under mixotrophic conditions, the presence of butyrate reduced the growth rate on acetate by $30 \%$ compared to the control without butyrate. However, VFAs complete removal was three days shorter under mixotrophic conditions than under heterotrophic conditions. The interactions between acetate, butyrate and inorganic carbon metabolisms under mixotrophic conditions 
appear to be complex and highly dependent on the initial concentration of butyrate. Indeed, butyrate inhibition is reduced in presence of light but not completely removed.

\subsection{Influence of temperature and $\mathrm{pH}$}

Despite the beneficial effects caused by an optimal temperature on microbial growth, such as enzymatic activity enhancement and reduction of the requirement for thermoregulation, temperature, and more specifically high temperature, could have adverse effects on microalgae growth on VFAs, and more particularly on mixotrophic growth. Indeed, the RuBisCO enzyme, which catalyzes $\mathrm{CO}_{2}$ fixation in the Calvin cycle, has a stronger oxidase activity at high temperature, meaning that $\mathrm{CO}_{2}$ fixation is reduced due to a higher photorespiration rate [51]. In addition, the value of pKa is linked to temperature and temperature variation may change the concentration of the undissociated toxic form of VFAs which would affect both the heterotrophic and mixotrophic microalgae growth. Effect of temperature on microalgae heterotrophic or mixotrophic growth on VFAs has been scarcely studied but the first results highlighted the importance of this parameter. When growing on a mixture of VFAs ,acetate:butyrate:propionate ratio of 6:3:1, the heterotrophic growth of Chlorella protothecoides was shown to be higher at $25^{\circ} \mathrm{C}$ than at $30^{\circ} \mathrm{C}$ [11] although this latter temperature is close to the optimal temperature for this species which is between $28^{\circ}$ and $30^{\circ} \mathrm{C}[11,52,53]$. Similarly, the heterotrophic growth of Chlorella sorokiniana on a mixture of acetate and butyrate (A:B ratio of 1:1) was the highest at $30^{\circ} \mathrm{C}$ than at $35{ }^{\circ} \mathrm{C}$ or $25^{\circ} \mathrm{C}$ due to a strong butyrate inhibition at $35^{\circ} \mathrm{C}$ although the optimal temperature for growing this species is ranging between $35-37^{\circ} \mathrm{C}$ [54-56]. The known optimal conditions for microalgal growth using a favorable single substrate cannot be applied when a mixture of substrates is investigated especially with the presence of inhibitory substrates such as butyrate. $\mathrm{pH}$ control during microalgal cultivation is requested in order to lower $\mathrm{pH}$-related inhibition caused by the uptake of VFAs, such as cytosolic $\mathrm{pH}$ acidification [43]. Indeed, at low $\mathrm{pH}$ values $(<\mathrm{pKa})$, acids are taken up under their undissociated form. Due to neutral $\mathrm{pH}$ of cytosol, acids are dissociated in the cytosol and $\mathrm{H}+$ are release, which leads to a decrease in $\mathrm{pH}$ value. Consequently, the microalgae growth can be reduced through inhibition of enzymes' reactions for example. In addition, without $\mathrm{pH}$ control, $\mathrm{pH}$ may increase due to the exhaustion of organic acids leading to an increase in toxic ammoniac $\left(\mathrm{NH}_{3}\right)$ if ammonium $\left(\mathrm{NH}_{4}{ }^{+}\right)$is present in the medium $\left(\mathrm{pKa} \mathrm{NH}{ }_{4}^{+} / \mathrm{NH}_{3}=9.5\right)$. A pH control, through automatic titration of either base or acid, was successfully used to increase biomass production by $38 \%$ and increase butyrate removal by $19 \%$ during mixotrophic growth of Chlorella vulgaris on butyrate [14]. As pointed out previously, when studying microalgae growth on VFAs, the control of $\mathrm{pH}$ has to be carefully considered to better understand the yields observed.

\section{Growth of microalgae on raw effluents: successes and challenges}




\subsection{Successful microalgae growth on raw effluents}

Despite the variability in the composition and concentrations of fermentation metabolites in raw effluents tested, Chlorella sp. and Scenedesmus sp. appeared to grow well on DF and AF effluents when using various operational strategies (Table 3).

\subsubsection{High acetate concentration lead to higher microalgae production}

High acetate concentration $\left(\geq 3\right.$ g. $\left.\mathrm{L}^{-1}\right)$ combined with high A:B ratio and $\mathrm{pH}$ control have been identified as key parameters to reduce the inhibitory effects caused by high initial concentrations of VFAs and thus promoting the microalgae growth on raw effluents (Table 3) (Cho et al., 2015; Hongyang et al., 2011; Hu et al., 2013, 2012; Ren et al., 2014a). Indeed, effluents with high total metabolites concentrations (> $5 \mathrm{~g} . \mathrm{L}^{-1}$ ), and with A:B ratio ranging from 4.5 to 20 , have been successfully used to reach high microalgae concentration $\left(\geq 2\right.$ g. $\left.\mathrm{L}^{-1}\right)$ even at high $\mathrm{S} / \mathrm{X}$ ratio (no dilution) under both heterotrophic and mixotrophic conditions [17,57].

To optimize the incompatible mechanisms of microalgae growth and lipids accumulation, the current trend is to favor the growth under $\mathrm{N}$ limitation which allows concomitant production of biomass and lipids, although the effect are strongly species dependent [59]. Interestingly, high lipid yields were also achieved on acetate ( $40 \%$ of dry weight), without applying a drastic $\mathrm{N}$ starvation, during the heterotrophic growth of Scenedesmus sp. on sterile raw DF effluents composed mainly of acetate and ethanol [7]. Since ethanol was not assimilated by Scenedesmus sp. [7], biomass yield and lipids production could be further enhanced by using ethanol-consumer species such as Crypthecodinium cohnii, Chlorella protothecoides and Chlorella sorokiniana (Table 2) [46,60,61].

As suggested by several authors, including Fei et al. (2014), microalgae grew well in fed-batch cultivation on raw effluents because VFAs concentration remained lower than the inhibitory level $(\leq 2$ g. $\mathrm{L}^{-1}$ ) due to the successive addition of the effluent [9]. As previously pointed out (sub-section 3.4), microalgae concentration and yields achieved under mixotrophic conditions have to be interpreted with caution. For example, the high biomass yield $\left(>1 \mathrm{~g} \cdot \mathrm{g}^{-1}\right)$ and microalgae concentration reached by Chlorella pyrenoidosa were probably due to both inorganic carbon uptake and also unidentified organic compounds from the effluents (Table 3) [12]. When acetate concentration was low (0.3 g.L $\left.\mathrm{L}^{-1}\right)$ because of dilution of the effluent (for which the total metabolites concentration was 11.4 g.L $\mathrm{L}^{-1}$ with no dilution), the final microalgae concentration was low $\left(0.35\right.$ g. $\left.\mathrm{L}^{-1}\right)$ despite a mixotrophic mode of assimilation and a A:B ratio of 10 (Table 3) (Hu et al., 2012). Since $\mathrm{pH}$ was neither controlled nor buffered, the AF effluent used in the study of $\mathrm{Hu}$ et al. (2012) had to be diluted 8 to 20 fold to avoid growth inhibition by the increase in $\mathrm{NH}_{3}$ concentration $[9,13]$. 


\subsubsection{Low S/X ratio and light supply used for low A:B ratio}

A low $\mathrm{S} / \mathrm{X}$ ratio (i.e. dilution of the effluent and/or increase of microalgae inoculum) and the presence of light and $\mathrm{CO}_{2}$ are favorable to grow microalgae on effluents having $\mathrm{A}: \mathrm{B}$ ratio lower than 1 $[14,15,18]$. As mentioned previously, the main drawback of diluting effluents is the low microalgae production due to the low initial VFAs concentration (Table 3). Liu et al. (2013) showed that butyrate uptake rate by Chlorella vulgaris was 10 times faster under optimized light intensity and without $\mathrm{CO}_{2}$ sparging, than under darkness (also without $\mathrm{CO}_{2}$ sparging) at low $\mathrm{S} / \mathrm{X}$ ratio. Nevertheless, by sparging air enriched with $30 \% \mathrm{CO}_{2}$ or under saturating light intensities, the beneficial effect of mixotrophy decreased, and butyrate uptake rate could also decrease by 20 to $30 \%$ as reported by Liu et al. (2013).

\subsection{Challenges arising from the use of raw effluents}

\subsubsection{Possible presence of inhibitors or low nutrient availability}

If we exclude the investigation of the influence of VFAs composition and concentrations, new challenges arise from the use of raw AF and DF effluents to sustain microalgae growth, and more particularly when considering real waste as feedstocks prior to fermentation, due to the presence of unknown and impacting compounds. When using food waste as substrate for AF and further growth of the fungi Cryptococcus albidus on AF effluent, the presence of unknown inhibitors was suggested by the authors $[19,62]$. Indeed, growth rate was twice higher when fungi was grown on synthetic AF effluents (mimicking VFAs composition of the real effluents) than on real AF effluents [19]. Nitrogen should not be limiting in DF effluents from protein-rich wastes fermentation such as food wastes [62]. On the opposite, Chi et al. ( 2011) hypothesized that ammonium concentration $\left(2.4\right.$ g. $\left.\mathrm{L}^{-1}\right)$ in the DF effluent from food waste equivalent to a $\mathrm{C}: \mathrm{N}$ ratio of 3.2:1 was too high to induce algal production of lipids from DF effluent. One of the main reasons to couple DF with microalgae growth is the availability of ammonium, orthophosphate and other nutrients (e.g; $\left.\mathrm{Mg}^{2+}\right)$ in the effluent which are mineralized from feedstock. Due to a lack of systematic screening of potential nutrients for algal growth in DF effluents, there are still no data available to conclude on sufficient nutrient availability to sustain efficiently the microalgae growth. Investigations on finding the optimal feedstock for an optimal coupling of hydrogen production by DF and subsequent microalgae growth and lipids accumulation are still required.

\subsubsection{Presence of suspended solids in untreated effluents}

Another issue linked to the use of untreated effluent is the presence of suspended solids that darken the medium and thus reduces the access to the light to sustain a mixotrophic growth [58]. By operating the HMG reactor under heterotrophic conditions, the presence of suspended solids should not alter the microalgae growth. If not, dilution or filtration of AF or DF effluents might be necessary to sustain mixotrophic conditions [58]. Owing to a 20-fold dilution of AF effluent from swine manure to ensure 
Chlorella sp. mixotrophic growth, acetate and butyrate concentrations were lowered to $0.3 \mathrm{~g} . \mathrm{L}^{-1}$ and 0.03 g. $\mathrm{L}^{-1}$, respectively. Consequently, low microalgae production, around $0.36 \mathrm{~g} . \mathrm{L}^{-1}$, was reached (Table 3). When dark effluents are used to support microalgae growth, cultivation under darkness (heterotrophy) might be more suitable than cultivation under light conditions (mixotrophy) in order to avoid the costs associated with the supply of light and the requirement of effluent dilution.

\subsubsection{Presence of Bacteria in unsterile effluents}

In order to couple efficiently DF and heterotrophic cultivation of microalgae, the cost of effluent sterilization has to be reduced. According to Park et al. (2014), sterilization of the medium accounts for more than one fourth of the investment costs of the process when coupling DF and oleaginous yeast cultivation. Bacterial contamination is one of the main challenges that must be resolved prior to upscaling heterotrophic cultivation [63]. During heterotrophic cultivation, the competition between microalgae and bacteria for carbon, nitrogen, phosphate and oxygen, is usually found to be unfavorable for microalgae growth $[64,65]$. Nevertheless, these authors suggested that some conditions may be favorable to microalgae growth, such as a low initial bacterial density and high initial nutrient loads. In unsterile municipal wastewaters, with high $\mathrm{NH}_{4}{ }^{+}$and $\mathrm{PO}_{4}{ }^{3-}$ loads and low organic carbon loads, Chlorella protothecoides has been shown to grow efficiently under autotrophic conditions [66]. As described in section 2, microbial community in DF and AF effluents is mainly composed of strict anaerobic and facultative anaerobic bacteria since protists and aerobic bacteria should not survive heat pretreatment of the inoculum and the strict anaerobic conditions of the fermentation process.

Few studies used successfully unsterile fermentation effluents for mixotrophic algal growth [9,13,18]. So far, the presence and the possible role of bacteria have not been extensively studied. Usually, bacterial growth is not monitored and microalgae growth is characterized by optical density or gravimetric methods which do not enable to distinguish microalgae and bacteria. Thus, one cannot distinguish between VFAs uptake by microalgae or by bacteria. For ensuring VFAs uptake by microalgae, monitoring microbial community is mandatory.

Recently, Turon et al. (2015b) investigated the heterotrophic growth of Chlorella sorokiniana in presence of fermentative bacteria on unsterile DF effluents, mainly composed of acetate and butyrate. Specific primers targeting either microalgae or bacteria were used to monitor both microalgal and bacterial growth by quantitative PCR. C sorokiniana outcompeted fermentative bacteria for acetate uptake thanks to a fast growth $\left(1.75 \mathrm{~d}^{-1}\right)$ on acetate and a delay in bacterial growth probably due to the drastic shift between operating conditions in DF (anaerobic conditions at $37^{\circ} \mathrm{C}$ ) to heterotrophy (aerobic conditions at $25^{\circ} \mathrm{C}$ ). Due to the high butyrate concentration $\left(1.2 \mathrm{~g} . \mathrm{L}^{-1}\right)$, C. sorokiniana was unable to grow on butyrate which was therefore entirely consumed by facultative and strict aerobic bacteria. Furthermore, such butyrate inhibition could also be reduced through the association of 
microalgae-bacteria which could lead to butyrate removal by bacteria [68]. As an illustration, Imase et al. (2008) built an artificial symbiosis between Chlorella sorokiniana and propionate-degrading bacteria and showed that propionate inhibition on microalgae was successfully lowered. Such strategy could be similarly used to lower the butyrate inhibition. In addition, the presence of the butyratedegrading bacteria could reduce the growth of aerobic fermentation bacteria since the ecological niche would already be established.

\section{Outlooks}

\subsection{Microalgae growth on raw effluents: a need for the development of new measurements and techniques}

The composition of organic carbon content, as well as inorganic nitrogen and phosphorus contents of dark fermentation (DF) effluents is not always fully determined. As an illustration, Hongyang et al. (2011) showed that $30 \%$ of the chemical oxygen demand (COD) of the effluent used to sustain Chlorella pyrenoidosa growth was not due to fermentation metabolites but was not characterized. Microalgae growth on this uncharacterized part of the organic matter cannot be analyzed. For $\mathrm{N}$ and $\mathrm{P}$ contents of DF effluents, they are usually not described even though the C:N:P ratio of the effluent may strongly influence the microalgae growth. In addition, the C:N ratio of the effluent would have a major impact on lipids production under $\mathrm{N}$ limitation (or $\mathrm{N}$ starvation) [20]. A thorough analysis of $\mathrm{C}$, $\mathrm{N}$ and $\mathrm{P}$ compounds of the effluent is thus recommended to investigate the coupling of DF and microalgae production.

An accurate quantification of the microalgae biomass (dry weight or cells number or equivalents) in presence of fermentative bacteria and suspended solids (originating from anaerobic sludge and the feedstock for fermentation) is also a major technical issue. Usually, the microalgae biomass $\left(\mathrm{g} . \mathrm{L}^{-1}\right)$ is estimated by direct weight measurement or indirectly either by optical density (OD) (turbidity), pigment extraction (Chlorophyll a), or via the bio-volume (using flow cytometry for example). But, the number of algal cells (measured directly by microscopic counting) is not necessarily linked to the dry weight since among a same species a great range of sizes is possible (daughter cells vs mother cells) [70] and the algal production of exudates (polysaccharides) may be also considered into the dry weight measurement. Since OD measurements do not discriminate bacteria, suspended solids and microalgae, the microalgae biomass cannot be quantified by using OD in raw effluents. Flow cytometry is a powerful tool to differentiate microalgae from bacteria thanks to the autofluorescence of chlorophyll, cells size and nucleus staining. However, the chlorophyll fluorescence might vary according to the mode of assimilation, i.e. heterotrophy or mixotrophy [71]. Moreover, samples would have to be filtered to remove the suspended solids before analysis. Counting microalgae using contrast phase or fluorescence microscopy would also be very difficult due to the high bacterial load and/or suspended solids. In several studies [67,72-74], microalgae were quantified in presence of bacteria 
and suspended solids using quantitative PCR with primers specific to microalgae. Although this method is accurate and does not require any filtration of the samples, results from qPCR analysis cannot be directly correlated to the dry weight. Indeed, results from qPCR are always analyzed using logarithmic values of the number of copies of the targeted genes which is due to the precision of the method. From a biological point of view, there is no strict correlation between the dry weight (or the cells number) and this logarithmic value. The only possible correlation would be between the dry weight (or the cells number) and the number of genes copies. Lakaniemi et al. (2012a) pointed out that the number of rDNA copy per cells may vary according to the growth phase. Even though monitoring the microalgal growth by qPCR has several advantages compared to the other techniques, several drawbacks exist and cannot be avoided. To monitor daily the microalgae and bacterial growths in reactors, no method is today readily available except microscopic counting, which also has several drawbacks.

Future research on carbon partitioning from VFAs, between microalgae and bacteria, would also be necessary to precisely estimate carbon assimilation by microalgae after DF. Indeed, under heterotrophic conditions and in presence of fermentative bacteria, Turon et al. (2015b) suggested that the microalgae growth was assumed to be only due to acetate uptake [67]. But the bacterial growth was observed during acetate removal. It was then suggested that bacteria might have grown on microalgae exudates or other unquantified organic compounds. In presence of light and $\mathrm{CO}_{2}$, it is difficult to differentiate between VFAs uptake by microalgae or bacteria. Indeed, microalgae growth could be due to $\mathrm{CO}_{2}$ assimilation and not VFAs uptake in presence of bacteria. After incubation with labeled carbon $\left({ }^{13} \mathrm{C} /{ }^{14} \mathrm{C}\right)$, e.g; labeled acetate and/or butyrate, flow cytometry coupled with cell sorting could be used to differentiate microalgae and bacteria and measure the incorporation of labeled carbon [76]. As pointed out by You et al. (2015), the traditional methods to differentiate microorganisms, bacteria and microalgae, according to the cell size (filtration, density gradient centrifugation and cell sorting) give poor results for bacteria and microalgae with similar abundance and cells sizes, as for Chlorella sorokiniana (2 and $6 \mu \mathrm{m}$ ). Very recently, You et al. (2015) developed a new method based on monitoring the assimilation of labeled carbon (NaHCO3) into the photosystem I (PSI), which is specific of microalgae since PSI is not present in heterotrophic bacteria . Obviously, if synthesis of PSI is down-regulated in presence of VFAs under heterotrophic conditions, the use of labelled VFAs tracking technique to follow their assimilation into labelled PSI should not be used, but another protein could be targeted, such a histone protein for example.

\subsection{Perspectives and challenges on coupling DF and microalgae heterotrophy}

One way to enhance the microalgae biomass production on raw fermentation effluents is to increase the microalgae competitiveness for butyrate uptake. Operating parameters, such as temperature, light, $\mathrm{pH}, \mathrm{S} / \mathrm{X}$ ratio could improve the microalgae competitiveness for butyrate uptake. In addition, previous acclimation of the microalgae to butyrate by successive cultures on media with low concentration of 
butyrate was suggested as another mean to reduce butyrate inhibition on microalgae growth [42]. Increasing acetate content (i.e. high acetate:butyrate ratio) in the effluent would also probably promote the microalgae growth on DF effluents. Theoretically, the $\mathrm{H}_{2}$ production through the acetate pathway is maximal (section 2) and increasing the acetate content is favorable to microalgae growth. Operating fermentation under thermophilic conditions is known to produce higher acetate content than butyrate content [78]. Combining thermophilic DF with microalgae growth could therefore be suggested as a promising coupling. Since VFA speciation is dependent on HRT, an increase of the HRT of the DF systems may lead to a higher A:B ratio through homoacetogenesis in detriment of $\mathrm{H}_{2}$ production. Further research is required to reach the best combination of both processes and maximize both $\mathrm{H}_{2}$ and acetate production together with microalgae biomass and lipids production.

Despite very promising microalgae biomass production (up to $4.08 \mathrm{~g} . \mathrm{L}^{-1}$ ) obtained on raw fermentation effluents[17], microalgae biomass and lipids productions still require further improvements to increase the economic feasibility of the coupling. Low cost dewatering systems have been suggested for increasing the VFAs concentration in the effluent and enhancing the microalgae production $[79,8]$. Among these systems, forward osmosis and pervaporation techniques have been highlighted as the most promising processes and are currently being optimized to maximize VFAs concentration in the effluents [79]. Once the VFAs concentrations are maximized, high cell density should be achieved as very high cell density (up to 109 g. $\mathrm{L}^{-1}$ ) have already been achieved under heterotrophic mode using chemical grade acetate as the substrate [80].

Additionally, a tradeoff between the reduction of butyrate inhibition on microalgae growth without enhancing the growth of unwanted bacteria would have to be investigated. Temperature and $\mathrm{pH}$ adjustments, as well as acetate enrichment, should promote microalgae growth and lower the butyrate inhibition but it might also promote bacterial growth during the heterotrophic step. Due to the competition with bacteria for organic carbon, microalgae might shift their metabolism towards autotrophy under mixotrophic conditions as a mean for survival. Finding an optimal S/X ratio to ensure the microalgae dominance over bacteria might be the most likely and reliable option.

The influence of the bacterial community structure on microalgae growth and competitiveness for VFAs should be further investigated to generalize the use of unsterilized effluent to sustain microalgae growth as previously suggested [67].

\section{Conclusion}

This review focused on analyzing and discussing microalgae growth on synthetic and raw fermentation effluents in order to highlight the potential of coupling processes of dark fermentation and microalgal growth. Before upscaling microalgae production on fermentation effluents, the effect of several abiotic (combination of $\mathrm{T}^{\circ}$, light, $\mathrm{CO}_{2}, \mathrm{pH}$ control) and biotic (selection of microalgae species and acclimation to butyrate) parameters still require additional research. Further analyses of 
fermentation effluents, in terms of $\mathrm{C}, \mathrm{N}$ and $\mathrm{P}$ compounds, and microbial (microalgae and bacteria) growth and interactions are required in order to get a better understanding and then a better control of the biomass and lipids production. Furthermore, future investigations related to the integration and engineering of these two processes would be necessary to find an optimal combination.

\section{Acknowledgment}

This work was funded by the National Institute of Agronomic Research (INRA) and the University of Montpellier, France. 


\section{References}

[1] Lee WS, Chua ASM, Yeoh HK, Ngoh GC. A review of the production and applications of waste-derived volatile fatty acids. Chem Eng J 2014;235:83-99. doi:10.1016/j.cej.2013.09.002.

[2] Ghimire A, Frunzo L, Pirozzi F, Trably E, Escudie R, Lens PNL, et al. A review on dark fermentative biohydrogen production from organic biomass: Process parameters and use of by-products. Appl Energy 2015;144:73-95. doi:10.1016/j.apenergy.2015.01.045.

[3] Chang HNH, Kim NNJ, Kang J, Jeong CCM. Biomass-derived volatile fatty acid platform for fuels and chemicals. Biotechnol Bioprocess Eng 2010;15:1-10.

[4] Guo XM, Trably E, Latrille E, Carrère H, Steyer J-P. Hydrogen production from agricultural waste by dark fermentation: A review. Int J Hydrogen Energy 2010;35:10660-73. doi:10.1016/j.ijhydene.2010.03.008.

[5] Park GW, Fei Q, Jung K, Chang HN, Kim Y-C, Kim N-J, et al. Volatile fatty acids derived from waste organics provide an economical carbon source for microbial lipids/biodiesel production. Biotechnol J 2014;9:1536-46. doi:10.1002/biot.201400266.

[6] Sambusiti C, Bellucci M, Zabaniotou A, Beneduce L, Monlau F. Algae as promising feedstocks for fermentative biohydrogen production according to a biorefinery approach: A comprehensive review. Renew Sustain Energy Rev 2015;44:20-36. doi:10.1016/j.rser.2014.12.013.

[7] Ren H-Y, Liu B-F, Kong F, Zhao L, Xing D, Ren N-Q. Enhanced energy conversion efficiency from high strength synthetic organic wastewater by sequential dark fermentative hydrogen production and algal lipid accumulation. Bioresour Technol 2014;157:355-9. doi:10.1016/j.biortech.2014.02.009.

[8] Singhania RR, Patel AK, Christophe G, Fontanille P, Larroche C. Biological upgrading of volatile fatty acids, key intermediates for the valorization of biowaste through dark anaerobic fermentation. Bioresour Technol 2013;145:166-74. doi:10.1016/j.biortech.2012.12.137.

[9] Hu B, Zhou W, Min M, Du Z, Chen P, Ma X, et al. Development of an effective acidogenically digested swine manure-based algal system for improved wastewater treatment and biofuel and feed production. Appl Energy 2013;107:255-63. doi:10.1016/j.apenergy.2013.02.033.

[10] Cai T, Park SY, Li Y. Nutrient recovery from wastewater streams by microalgae: Status and prospects. Renew Sustain Energy Rev 2013;19:360-9. doi:10.1016/j.rser.2012.11.030.

[11] Fei Q, Fu R, Shang L, Brigham CJ, Chang HN. Lipid production by microalgae Chlorella protothecoides with volatile fatty acids (VFAs) as carbon sources in heterotrophic cultivation and its economic assessment. Bioprocess Biosyst Eng 2014;38:691-700. doi:10.1007/s00449-014-1308-0.

[12] Hongyang S, Yalei Z, Chunmin Z, Xuefei Z, Jinpeng L. Cultivation of Chlorella pyrenoidosa in soybean processing wastewater. Bioresour Technol 2011;102:9884-90. doi:10.1016/j.biortech.2011.08.016.

[13] Hu B, Min M, Zhou W, Du Z, Mohr M, Chen P, et al. Enhanced mixotrophic growth of microalga Chlorella sp. on pretreated swine manure for simultaneous biofuel feedstock production and nutrient removal. Bioresour Technol 2012;126:71-9. doi:10.1016/j.biortech.2012.09.031.

[14] Liu C-H, Chang C-Y, Liao Q, Zhu X, Chang J-S. Photoheterotrophic growth of Chlorella vulgaris ESP6 on organic acids from dark hydrogen fermentation effluents. Bioresour Technol 2012;145:331-6. doi:10.1016/j.biortech.2012.12.111.

[15] Liu C-H, Chang C-Y, Liao Q, Zhu X, Liao C-F, Chang J-S. Biohydrogen production by a novel integration of dark fermentation and mixotrophic microalgae cultivation. Int J Hydrogen Energy 2013;38:15807-14. doi:10.1016/j.ijhydene.2013.05.104.

[16] Moon M, Kim CW, Park W-K, Yoo G, Choi Y-E, Yang J-W. Mixotrophic growth with acetate or volatile fatty acids maximizes growth and lipid production in Chlamydomonas reinhardtii. Algal Res 2013;2:352-7. doi:10.1016/j.algal.2013.09.003.

[17] Cho HU, Kim YM, Choi Y-N, Xu X, Shin DY, Park JM. Effects of pH control and concentration on microbial oil production from Chlorella vulgaris cultivated in the effluent of a low-cost organic waste fermentation system producing volatile fatty acids. Bioresour Technol 2015;184:245-50. doi:10.1016/j.biortech.2014.09.069.

[18] Venkata Mohan S, Prathima Devi M. Fatty acid rich effluent from acidogenic biohydrogen reactor as substrate for lipid accumulation in heterotrophic microalgae with simultaneous treatment. Bioresour Technol 2012;123:627-35. doi:10.1016/j.biortech.2012.07.004.

[19] Vajpeyi S, Chandran K. Microbial conversion of synthetic and food waste-derived volatile fatty acids to lipids. Bioresour Technol 2015;188:49-55. doi:10.1016/j.biortech.2015.01.099.

[20] Fei Q, Chang HN, Shang L, Choi J, Kim N, Kang J. The effect of volatile fatty acids as a sole carbon source on lipid accumulation by Cryptococcus albidus for biodiesel production. Bioresour Technol 2011;102:2695-701. doi:10.1016/j.biortech.2010.10.141.

[21] Saady NMC. Homoacetogenesis during hydrogen production by mixed cultures dark fermentation: Unresolved challenge. Int J Hydrogen Energy 2013;38:13172-91. doi:10.1016/j.ijhydene.2013.07.122. 
[22] Monlau F, Barakat A, Trably E, Dumas C, Steyer J, Carrère H. Lignocellulosic Materials Into Biohydrogen and Biomethane: Impact of Structural Features and Pretreatment. Crit Rev Environ Sci Technol 2013;43:260-322. doi:10.1080/10643389.2011.604258.

[23] Wong YM, Wu TY, Juan JC. A review of sustainable hydrogen production using seed sludge via dark fermentation. Renew Sustain Energy Rev 2014;34:471-82. doi:10.1016/j.rser.2014.03.008.

[24] Jobard M, Pessiot J, Nouaille R, Sime-Ngando T. Microbial diversity supporting dark fermentation of waste. Trends Biotechnol 2014;32:549-50. doi:10.1016/j.tibtech.2014.09.005.

[25] Ntaikou I, Antonopoulou G, Lyberatos G. Biohydrogen production from biomass and wastes via dark fermentation: A review. Waste and Biomass Valorization 2010;1:21-39. doi:10.1007/s12649-009-90012.

[26] Hawkes F, Hussy I, Kyazze G, Dinsdale R, Hawkes D. Continuous dark fermentative hydrogen production by mesophilic microflora: Principles and progress. Int J Hydrogen Energy 2007;32:172-84. doi:10.1016/j.ijhydene.2006.08.014.

[27] Lin P-Y, Whang L-M, Wu Y-R, Ren W-J, Hsiao C-J, Li S-L, et al. Biological hydrogen production of the genus Clostridium: Metabolic study and mathematical model simulation. Int J Hydrogen Energy 2007;32:1728-35. doi:10.1016/j.ijhydene.2006.12.009.

[28] Guo XM, Trably E, Latrille E, Carrere H, Steyer JP. Predictive and explicative models of fermentative hydrogen production from solid organic waste: Role of butyrate and lactate pathways. Int J Hydrogen Energy 2013;9:3-12. doi:10.1016/j.ijhydene.2013.08.079.

[29] Rafrafi Y, Trably E, Hamelin J, Latrille E, Meynial-Salles I, Benomar S, et al. Sub-dominant bacteria as keystone species in microbial communities producing bio-hydrogen. Int J Hydrogen Energy 2013;38:4975-85. doi:10.1016/j.ijhydene.2013.02.008.

[30] Davila-Vazquez G, Arriaga S, Alatriste-Mondragón F, De León-Rodríguez A, Rosales-Colunga LM, Razo-Flores E. Fermentative biohydrogen production: Trends and perspectives. Rev Environ Sci Biotechnol 2008;7:27-45. doi:10.1007/s11157-007-9122-7.

[31] Moletta R. La méthanisation. TEC ET DOC. 2008.

[32] Gómez X, Fernández C, Fierro J, Sánchez ME, Escapa A, Morán A. Hydrogen production: two stage processes for waste degradation. Bioresour Technol 2011;102:8621-7. doi:10.1016/j.biortech.2011.03.055.

[33] Moon C, Jang S, Yun Y-M, Lee M-K, Kim D-H, Kang W-S, et al. Effect of the accuracy of pH control on hydrogen fermentation. Bioresour Technol 2014;179:595-601. doi:10.1016/j.biortech.2014.10.128.

[34] Zhu Y, Yang S-T. Effect of $\mathrm{pH}$ on metabolic pathway shift in fermentation of xylose by Clostridium tyrobutyricum. J Biotechnol 2004;110:143-57. doi:10.1016/j.jbiotec.2004.02.006.

[35] Sarma SJ, Pachapur V, Brar SK, Le Bihan Y, Buelna G. Hydrogen biorefinery: Potential utilization of the liquid waste from fermentative hydrogen production. Renew Sustain Energy Rev 2015;50:942-51. doi:10.1016/j.rser.2015.04.191.

[36] Kovárová-kovar K, Egli T. Growth kinetics of suspended microbial cells: from single-substratecontrolled growth to mixed-substrate kinetics. Microbiol Mol Biol Rev 1998;62:646-66.

[37] Egli T, Lendenmann U, Snozzi M. Kinetics of microbial growth with mixtures of carbon sources. Int J Gen Mol Microbiol 1993;63:289-98. doi:10.1007/BF00871224.

[38] Perez-Garcia O, Escalante FME, De-Bashan LE, Bashan Y. Heterotrophic cultures of microalgae: metabolism and potential products. Water Res 2011;45:11-36. doi:10.1016/j.watres.2010.08.037.

[39] Kurihara T, Ueda M, Okada H, Kamasawa N, Naito N, Osumi M, et al. Beta-oxidation of butyrate, the short-chain-length fatty acid, occurs in peroxisomes in the yeast Candida tropicalis. J Biochem 1992;111:783-7.

[40] Heredia-Arroyo T, Wei W, Ruan R, Hu B. Mixotrophic cultivation of Chlorella vulgaris and its potential application for the oil accumulation from non-sugar materials. Biomass and Bioenergy 2011;35:224553. doi:10.1016/j.biombioe.2011.02.036

[41] Chang HN, Fei Q, Choi JDR, Kim NJ, Kin W. Method of producing microbial intracellular products from volatile fatty acids. US Patent 2012 / 0219993 A1, 2012.

[42] Turon V, Baroukh C, Trably E, Latrille E, Fouilland E, Steyer J-P. Use of fermentative metabolites for heterotrophic microalgae growth: Yields and kinetics. Bioresour Technol 2015;175:342-9. doi:10.1016/j.biortech.2014.10.114.

[43] Lin X, Xiong L, Qi G, Shi S, Huang C, Chen X, et al. Using butanol fermentation wastewater for biobutanol production after removal of inhibitory compounds by micro-mesoporous hyper cross linked polymeric adsorbent. ACS Sustain Chem Eng 2015;3:702-9. doi:10.1021/acssuschemeng.5b00010.

[44] Chapman SP, Paget CM, Johnson GN, Schwartz J-M. Flux balance analysis reveals acetate metabolism modulates cyclic electron flow and alternative glycolytic pathways in Chlamydomonas reinhardtii. Front Plant Sci 2015;6:1-14. doi:10.3389/fpls.2015.00474. 
[45] Smith RT, Bangert K, Wilkinson SJ, Gilmour DJ. Synergistic carbon metabolism in a fast growing mixotrophic freshwater microalgal species Micractinium inermum. Biomass and Bioenergy 2015;In press. doi:10.1016/j.biombioe.2015.04.023.

[46] Lowrey J, Brooks MS, McGinn PJ. Heterotrophic and mixotrophic cultivation of microalgae for biodiesel production in agricultural wastewaters and associated challenges - a critical review. J Appl Phycol 2015;27:1485-98. doi:10.1007/s10811-014-0459-3.

[47] Zhang L. Butyric and docosahexaenoic acids production from hemicellulose. 2012.

[48] Narang A, Pilyugin S. Towards an integrated physiological theory of microbial growth: from subcellular variables to population dynamics. Math Biosci Eng 2005;2:173-210.

[49] Bumbak F, Cook S, Zachleder V, Hauser S, Kovar K. Best practices in heterotrophic high-cell-density microalgal processes: Achievements, potential and possible limitations. Appl Microbiol Biotechnol 2011;91:31-46. doi:10.1007/s00253-011-3311-6.

[50] Turon V, Trably E, Fouilland E, Steyer J. Growth of Chlorella sorokiniana on a mixture of volatile fatty acids : the effects of light and temperature This study investigated the influence of light and temperature on Chlorella sorokiniana. Bioresour Technol 2015;198:852-60. doi:10.1016/j.biortech.2015.10.001.

[51] Bernacchi CJ, Singsaas EL, Pimentel C, Portis a. R, Long SP. Improved temperature response functions for models of Rubisco-limited photosynthesis. Plant, Cell Environ 2001;24:253-9. doi:10.1046/j.13653040.2001.00668.x.

[52] Shi X, Wu Z, Chen F. Kinetic modeling of lutein production by heterotrophic Chlorella at various $\mathrm{pH}$ and temperatures. Mol Nutr Food Res 2006;50:763-8. doi:10.1002/mnfr.200600037.

[53] Sforza E, Ramos-Tercero EA, Gris B, Bettin F, Milani A, Bertucco A. Integration of Chlorella protothecoides production in wastewater treatment plant: From lab measurements to process design. Algal Res 2014;6:223-33. doi:10.1016/j.algal.2014.06.002.

[54] Janssen M, Kuijpers TC, Veldhoen B, Ternbach MB, Tramper J, Mur LR, et al. Specific growth rate of Chlamydomonas reinhardtii and Chlorella sorokiniana under medium duration light/dark cycles: 13-87 s. Prog Ind Microbiol 1999;35:323-33. doi:10.1016/S0079-6352(99)80124-6.

[55] Li T, Zheng Y, Yu L, Chen S. Mixotrophic cultivation of a Chlorella sorokiniana strain for enhanced biomass and lipid production. Biomass and Bioenergy 2014;66:204-13. doi:10.1016/j.biombioe.2014.04.010.

[56] Van Wagenen J, Holdt SL, De Francisci D, Valverde-Pérez B, Plósz BG, Angelidaki I. Microplate-based method for high-throughput screening of microalgae growth potential. Bioresour Technol 2014;169:56672. doi:10.1016/j.biortech.2014.06.096.

[57] Ren H-Y, Liu B-F, Kong F, Zhao L, Xie G-J, Ren N-Q. Enhanced lipid accumulation of green microalga Scenedesmus sp. by metal ions and EDTA addition. Bioresour Technol 2014. doi:10.1016/j.biortech.2014.06.062.

[58] Hu B, Min M, Zhou W, Du Z, Mohr M, Chen P, et al. Enhanced mixotrophic growth of microalga Chlorella sp. on pretreated swine manure for simultaneous biofuel feedstock production and nutrient removal. Bioresour Technol 2012;126:71-9. doi:10.1016/j.biortech.2012.09.031.

[59] Adams C, Godfrey V, Wahlen B, Seefeldt L, Bugbee B. Understanding precision nitrogen stress to optimize the growth and lipid content tradeoff in oleaginous green microalgae. Bioresour Technol 2013;131:188-94. doi:10.1016/j.biortech.2012.12.143.

[60] Sforza E, Cipriani R, Morosinotto T, Bertucco A, Giacometti GM. Excess CO2 supply inhibits mixotrophic growth of Chlorella protothecoides and Nannochloropsis salina. Bioresour Technol 2012;104:523-9. doi:10.1016/j.biortech.2011.10.025.

[61] Ogbonna JC, Tanaka H. Cyclic autotrophic/heterotrophic cultivation of photosynthetic cells: A method of achieving continuous cell growth under light/dark cycles. Bioresour Technol 1998;65:65-72. doi:10.1016/S0960-8524(98)00018-2.

[62] Chi Z, Zheng Y, Ma J, Chen S. Oleaginous yeast Cryptococcus curvatus culture with dark fermentation hydrogen production effluent as feedstock for microbial lipid production. Int J Hydrogen Energy 2011;36:9542-50. doi:10.1016/j.ijhydene.2011.04.124.

[63] Rashid N, Ur Rehman MS, Sadiq M, Mahmood T, Han J-I. Current status, issues and developments in microalgae derived biodiesel production. Renew Sustain Energy Rev 2014;40:760-78. doi:10.1016/j.rser.2014.07.104.

[64] Zhang Y, Su H, Zhong Y, Zhang C, Shen Z, Sang W, et al. The effect of bacterial contamination on the heterotrophic cultivation of Chlorella pyrenoidosa in wastewater from the production of soybean products. Water Res 2012;46:5509-16. doi:10.1016/j.watres.2012.07.025.

[65] Kamjunke N, Köhler B, Wannicke N, Tittel J. Algae as competitors for glucose with heterotrophic bacteria. J Phycol 2008;44:616-23. doi:10.1111/j.1529-8817.2008.00520.x. 
[66] Ramos Tercero EA, Sforza E, Morandini M, Bertucco A. Cultivation of Chlorella protothecoides with urban wastewater in continuous photobioreactor: biomass productivity and nutrient removal. Appl Biochem Biotechnol 2014;172:1470-85. doi:10.1007/s12010-013-0629-9.

[67] Turon V, Trably E, Fayet A, Fouilland E, Steyer J-P. Raw dark fermentation effluent to support heterotrophic microalgae growth: microalgae successfully outcompete bacteria for acetate. Algal Res 2015;12:119-25. doi:10.1016/j.algal.2015.08.011.

[68] Tate JJ, Gutierrez-Wing MT, Rusch K a., Benton MG. The Effects of Plant Growth Substances and Mixed Cultures on Growth and Metabolite Production of Green Algae Chlorella sp.: A Review. J Plant Growth Regul 2013;32:417-28. doi:10.1007/s00344-012-9302-8.

[69] Imase M, Watanabe K, Aoyagi H, Tanaka H. Construction of an artificial symbiotic community using a Chlorella-symbiont association as a model. FEMS Microbiol Ecol 2008;63:273-82. doi:10.1111/j.15746941.2007.00434.x.

[70] Richmond A, Hu Q, editors. The Microalgal cell with reference to mass culture. Handb. Microalgal Cult. Appl. Phycol. Biotechnol. Second Ed. Willey Bla, 2013.

[71] Rosenberg JN, Kobayashi N, Barnes A, Noel EA, Betenbaugh MJ, Oyler GA. Comparative analyses of three Chlorella species in response to light and sugar reveal distinctive lipid accumulation patterns in the microalga C. sorokiniana. PLoS One 2014;9:e92460. doi:10.1371/journal.pone.0092460.

[72] Fowler RF. Development of a specific quantitative real-time PCR assay to monitor Chlorella DNA: A case study from mammoth cave national park, Kentucky, USA. Acta Carsologica 2011;40:381-90.

[73] Lakaniemi A-M, Intihar VM, Tuovinen OH, Puhakka J a. Growth of Chlorella vulgaris and associated bacteria in photobioreactors. Microb Biotechnol 2012;5:69-78. doi:10.1111/j.1751-7915.2011.00298.x.

[74] Coyne KJ, Handy SM, Demir E, Whereat EB, Hutchins D a., Portune KJ, et al. Improved quantitative real-time PCR assays for enumeration of harmful algal species in field samples using an exogenous DNA reference standard. Limnol Oceanogr Methods 2005;3:381-91. doi:10.4319/lom.2005.3.381.

[75] Lakaniemi A-M, Hulatt CJ, Wakeman KD, Thomas DN, Puhakka J a. Eukaryotic and prokaryotic microbial communities during microalgal biomass production. Bioresour Technol 2012;124:387-93. doi:10.1016/j.biortech.2012.08.048.

[76] Hartmann M, Zubkov M V, Martin AP, Scanlan DJ, Burkill PH. Assessing amino acid uptake by phototrophic nanoflagellates in nonaxenic cultures using flow cytometric sorting. FEMS Microbiol Lett 2009;298:166-73. doi:10.1111/j.1574-6968.2009.01715.x.

[77] You L, Liu H, Blankenship RE, Tang YJ. Using photosystem I as a reporter protein for 13C analysis in a coculture containing cyanobacterium and a heterotrophic bacterium. Anal Biochem 2015;477:86-8. doi:10.1016/j.ab.2014.12.005.

[78] Verhaart MR a, Bielen A a M, van der Oost J, Stams AJM, Kengen SWM. Hydrogen production by hyperthermophilic and extremely thermophilic bacteria and archaea: mechanisms for reductant disposal. Environ Technol 2010;31:993-1003. doi:10.1080/09593331003710244.

[79] Yup S, Nam H, Kim Y. Permeation characteristics of volatile fatty acids solution by forward osmosis. Process Biochem 2015:1-9. doi:10.1016/j.procbio.2015.01.016.

[80] De Swaaf ME, Sijtsma L, Pronk JT. High-cell-density fed-batch cultivation of the docosahexaenoic acid producing marine alga Crypthecodinium cohnii. Biotechnol Bioeng 2003;81:666-72. doi:10.1002/bit.10513.

[81] Datar R, Huang J, Maness PC, Mohagheghi A, Czernik S, Chornet E. Hydrogen production from the fermentation of corn stover biomass pretreated with a steam-explosion process. Int J Hydrogen Energy 2007;32:932-9. doi:10.1016/j.ijhydene.2006.09.027.

[82] Marone A, Varrone C, Fiocchetti F, Giussani B, Izzo G, Mentuccia L, et al. Optimization of substrate composition for biohydrogen production from buffalo slurry co-fermented with cheese whey and crude glycerol, using microbial mixed culture. Int J Hydrogen Energy 2015;40:209-18. doi:10.1016/j.ijhydene.2014.11.008.

[83] Han S-K, Shin H-S. Performance of an innovative two-stage process converting food waste to hydrogen and methane. J Air Waste Manag Assoc 2004;54:242-9. doi:10.1080/10473289.2004.10470895.

[84] Fang HHP, Li C, Zhang T. Acidophilic biohydrogen production from rice slurry. Int J Hydrogen Energy 2006;31:683-92. doi:10.1016/j.ijhydene.2005.07.005.

[85] Fan YT, Zhang YH, Zhang SF, Hou HW, Ren BZ. Efficient conversion of wheat straw wastes into biohydrogen gas by cow dung compost. Bioresour Technol 2006;97:500-5. doi:10.1016/j.biortech.2005.02.049.

[86] Zhang ML, Fan YT, Xing Y, Pan CM, Zhang GS, Lay JJ. Enhanced biohydrogen production from cornstalk wastes with acidification pretreatment by mixed anaerobic cultures. Biomass and Bioenergy 2007;31:250-4. doi:10.1016/j.biombioe.2006.08.004 
[87] Chairattanamanokorn P, Penthamkeerati P, Reungsang A, Lo YC, Lu W Bin, Chang JS. Production of biohydrogen from hydrolyzed bagasse with thermally preheated sludge. Int J Hydrogen Energy 2009;34:7612-7. doi:10.1016/j.ijhydene.2009.07.034.

[88] Dahiya S, Sarkar O, Swamy YV, Mohan SV. Acidogenic fermentation of food waste for volatile fatty acid production along with co-generation of biohydrogen. Bioresour Technol 2015;182:103-13. doi:10.1016/j.biortech.2015.01.007.

[89] Cho HU, Kim YM, Choi Y-N, Xu X, Shin DY, Park JM. Effects of pH control and concentration on microbial oil production from Chlorella vulgaris cultivated in the effluent of a low-cost organic waste fermentation system producing volatile fatty acids. Bioresour Technol 2015;184:245-50. doi:10.1016/j.biortech.2014.09.069.

[90] Sforza E, Cipriani R, Morosinotto T, Bertucco A, Giacometti GM. Excess CO 2 supply inhibits mixotrophic growth of Chlorella protothecoides and Nannochloropsis salina. Bioresour Technol 2012;104:523-9. doi:10.1016/j.biortech.2011.10.025.

[91] Ogbonna JC, Yoshizawa H, Tanaka H. Treatment of high strength organic wastewater by a mixed culture of photosynthetic microorganisms. J Appl Phycol 2000;12:277-84.

[92] De Swaaf ME, Pronk JT, Sijtsma L. Fed-batch cultivation of the docosahexaenoic-acid-producing marine alga Crypthecodinium cohnii on ethanol. Appl Microbiol Biotechnol 2003;61:40-3. doi:10.1007/s00253-002-1118-1.

[93] Ratledge IC, Gb B, Anderson J, Gb H, Kanagachandran K. Culture of Crypthecodinium cohnii and microorganisms derived therefrom, 2010.

[94] Ogbonna JC, Tomiyama S, Tanaka H. Heterotrophic cultivation of Euglena gracilis Z for efficient production of -tocopherol 1998:67-74.

[95] Ren H-Y, Liu B-F, Ma C, Zhao L, Ren N-Q. A new lipid-rich microalga Scenedesmus sp. strain R-16 isolated using Nile red staining: effects of carbon and nitrogen sources and initial $\mathrm{pH}$ on the biomass and lipid production. Biotechnol Biofuels 2013;6:1-10. doi:10.1186/1754-6834-6-143. 


\section{Figure Captions}

Figure 1. Schematic representation of coupling dark fermentation with microalgae growth for

gaseous and liquid fuels. HRT: Hydraulic retention time, A:B : Acetate:butyrate, S/X:

substrate/microalgae

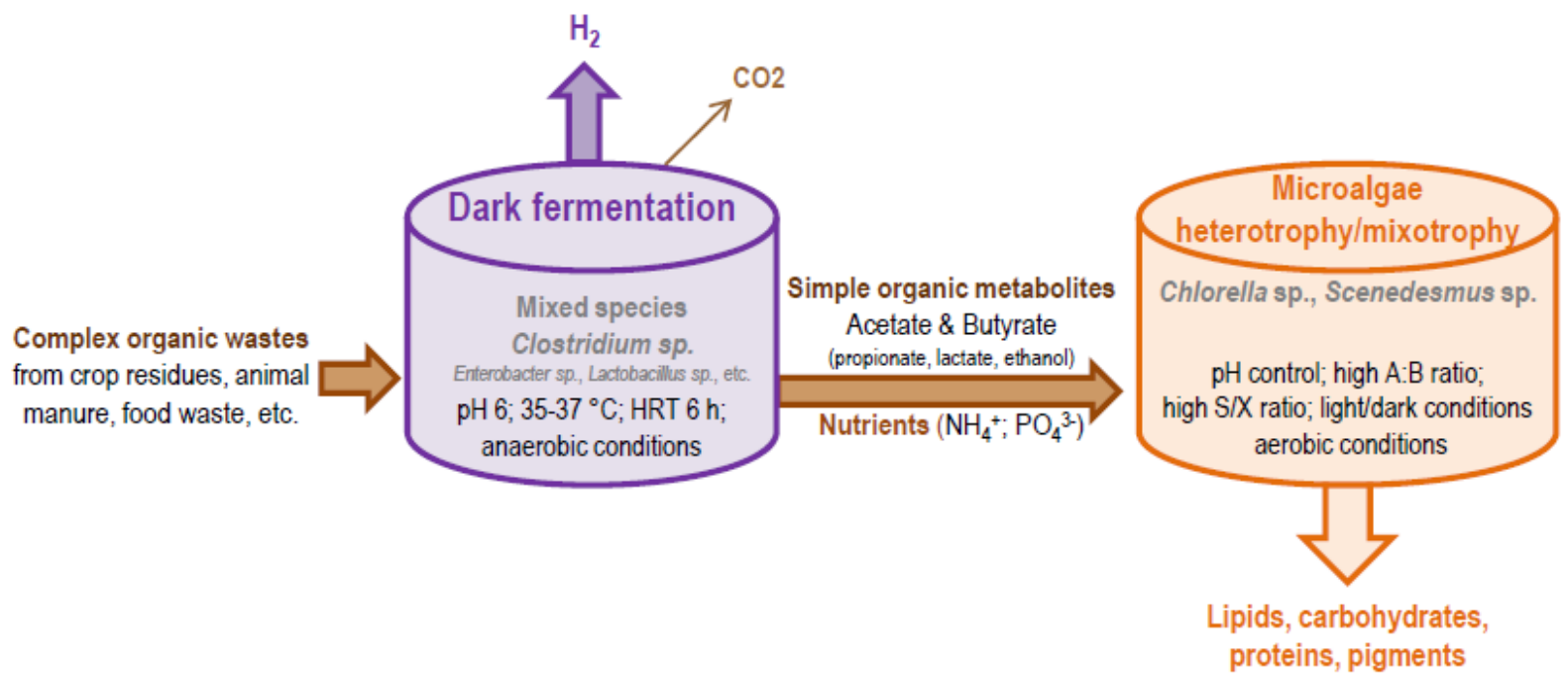


Figure 2. Links between anaerobic digestion, acidogenic fermentation and dark fermentation.

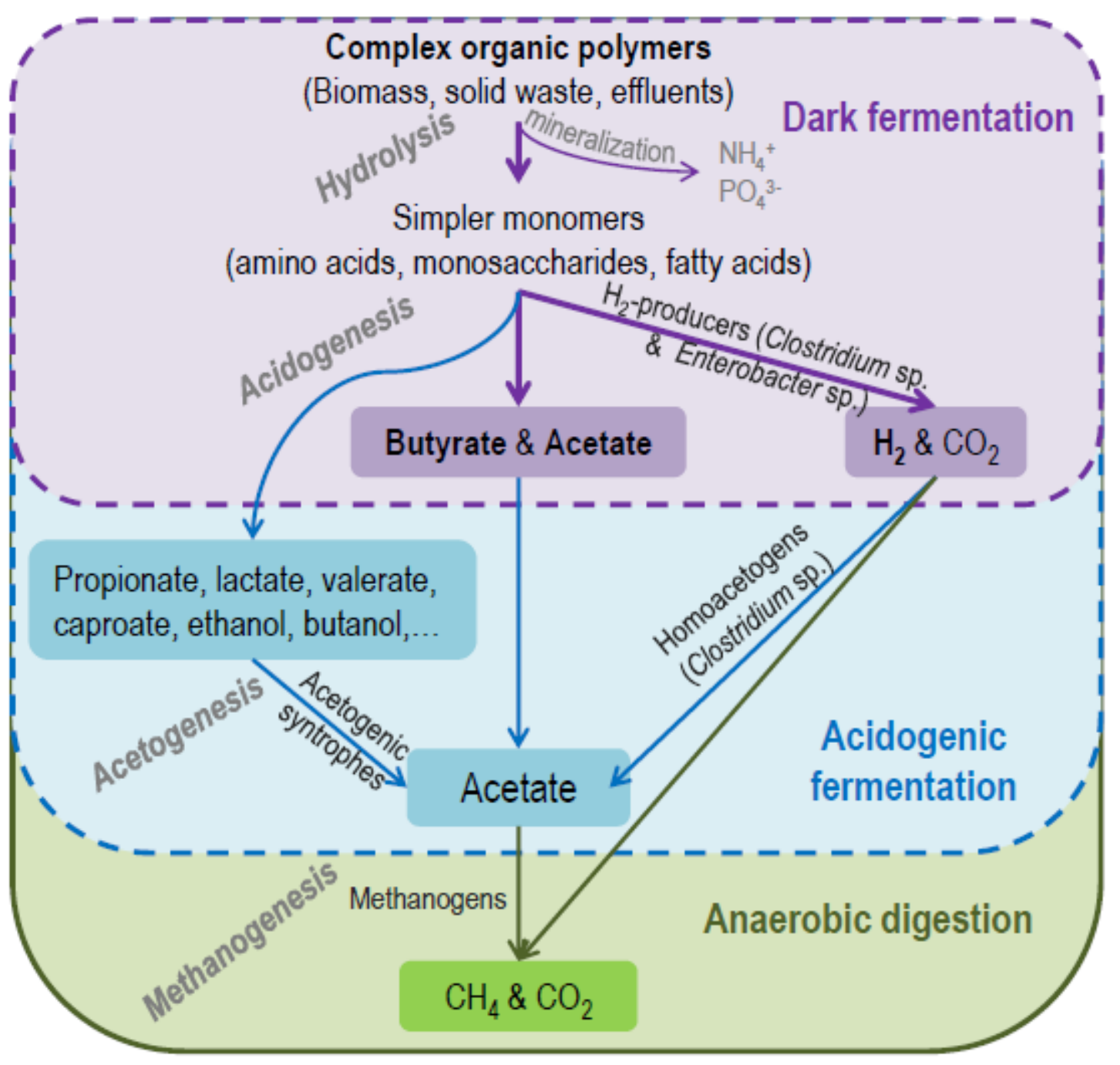




\section{Tables}

Table1. Examples of $\mathrm{H}_{2}$ and metabolites production according to the waste feedstock and operational conditions.

\begin{tabular}{|c|c|c|c|c|c|c|c|c|c|c|c|}
\hline $\begin{array}{l}\text { Feedstock } \\
\text { (organic load) }\end{array}$ & Inoculum & $\begin{array}{l}\text { Culture } \\
\text { mode }\end{array}$ & $\mathrm{pH}$ & $\begin{array}{c}\mathrm{T} \\
{ }^{\circ} \mathrm{C}\end{array}$ & $\mathrm{H}_{2}$ & \begin{tabular}{|l|} 
Acetate \\
$\left(\mathrm{g} . \mathrm{L}^{-1}\right)$
\end{tabular} & \begin{tabular}{|l|} 
Butyrate \\
$\left(\right.$ g.L $\left.\mathrm{L}^{-1}\right)$
\end{tabular} & \begin{tabular}{|l|} 
Ethanol \\
$\left(\mathrm{g} . \mathrm{L}^{-1}\right)$
\end{tabular} & \begin{tabular}{|l} 
Lactate \\
$\left(\mathrm{g} . \mathrm{L}^{-1}\right)$
\end{tabular} & \begin{tabular}{|c|} 
Propionate \\
$\left(\mathrm{g} . \mathrm{L}^{-1}\right)$ \\
\end{tabular} & Reference \\
\hline Food waste $\left(60 \mathrm{~g} \mathrm{VS.L^{-1 }}\right)$ & Anaerobic sludge (HT) & B & 8 & 35 & $289^{a}$ & 12.2 & 6.7 & & & 0.7 & [62] \\
\hline $\begin{array}{l}\text { Hydrolyzate of corn stover } \\
\left(5.5 \mathrm{~g} . \mathrm{L}^{-1} \text { of mixed sugars }\right)\end{array}$ & Anaerobic sludge (HT) & $\mathrm{B}$ & 5.5 & 35 & $2.84^{b}$ & 0.57 & 0.88 & & & & [81] \\
\hline $\begin{array}{c}\text { Buffalo slurry and cheese whey } \\
\left(20.6 \mathrm{gVS}^{-1} \mathrm{~L}^{-1}\right)\end{array}$ & Lagoon sediments & B & 6.5 & 37 & $117^{\mathrm{a}}$ & 0.85 & 2.04 & 0.51 & 0.1 & 2.8 & {$[82]$} \\
\hline Food waste (13 g COD.L $\left.{ }^{-1}\right)$ & Anaerobic sludge (HT) & $\mathrm{C}^{*}$ & 6.5 & 37 & $310^{\mathrm{a}}$ & $0.5^{\mathrm{e}}$ & $0.8^{\mathrm{e}}$ & $0.9^{\mathrm{e}}$ & $0.9^{\mathrm{e}}$ & $0.2^{\mathrm{e}}$ & {$[83]$} \\
\hline $\begin{array}{c}\text { Rice slurry (5.5 g.L } \mathrm{L}^{-1} \text { of } \\
\text { carbohydrates) }\end{array}$ & Anaerobic sludge (HT) & B & 4.5 & 37 & $346^{c}$ & 0.9 & 2.3 & 0 & 0 & 0 & [84] \\
\hline Wheat straw $\left(25\right.$ g.. L $\left.^{-1}\right)$ & $\begin{array}{l}\text { Cow dung compost } \\
\text { (UV-treated) }\end{array}$ & B & 7 & 36 & $68.1^{\mathrm{a}}$ & 1.6 & 1.6 & 0.48 & 0 & $<0.4$ & {$[85]$} \\
\hline Cornstalk waste $\left(15 \mathrm{~g} . \mathrm{L}^{-1}\right)$ & Cow dung compost & B & 7 & 36 & $150^{\mathrm{a}}$ & 0.9 & 1.1 & 0.25 & 0 & 0.7 & {$[86]$} \\
\hline Hydrolyzed bagasse $\left(10\right.$ g.L L $\left.^{-1}\right)$ & Anaerobic sludge (HT) & B & 5.4 & 50 & $13.39^{\mathrm{d}}$ & & 0.8 & & 0.3 & & [87] \\
\hline Food waste (15 g COD.L $\left.{ }^{-1}\right)$ & Anaerobic sludge & B & 10 & 28 & $0(\mathrm{AF})^{\mathrm{d}}$ & 4 & $0.6-0.7$ & 0 & 0 & 1 & {$[88]$} \\
\hline
\end{tabular}


a: mL H2 gVS-1; b: mol H2 per mol of sugars consumed; c: mL H2.g-1 of carbohydrates; d: mL H2.gTSadded-1; added; f: Acidogenic fermentation; e: maximal metabolites concentration during fermentation. VS: Volatile Solids, TS: Total Solids; *: HRT: 2.3 - 4.5 d-1; T: Temperature; HT: Heat-treated; B:

Batch; C: Continuous 
Table 2. Overview of fermentation metabolites used as substrates to sustain microalgae growth.

\begin{tabular}{|l|l|l|l|l|l|l|}
\hline Species & Acetate & Butyrate & Propionate & Ethanol & Lactate & Reference \\
\hline Chlamydomonas reinhardtii & + & + & + & & & {$[16]$} \\
\hline Chlorella vulgaris & + & + & & & - & {$[14]$} \\
\hline & + & + & + & & & {$[89]$} \\
\hline \multirow{5}{*}{ (Auxeno)Chlorella protothecoides } & + & + & & & - & {$[42]$} \\
\hline & + & + & + & & & {$[11]$} \\
\hline & + & & & + & & {$[90]$} \\
\hline \multirow{5}{*}{ Chlorella sorokiniana } & + & & - & & & {$[91]$} \\
\hline & + & + & & & - & {$[42]$} \\
\hline & + & & & + & & {$[61]$} \\
\hline Crypthecodium cohnii ${ }^{a}$ & + & + & & & + & {$[47]$} \\
\hline & & & & + & & {$[92]$} \\
\hline & + & & + & & & {$[93]$} \\
\hline Euglena gracilis & & & & + & & {$[94]$} \\
\hline Scenedesmus sp. & + & & & - & & {$[7]$} \\
\hline & + & + & $+{ }^{\mathrm{b}}$ & & & {$[95]$} \\
\hline
\end{tabular}

${ }^{\mathrm{a}}$ : apochloroplastic species (strict heterotroph); ${ }^{\text {b}}$ : very low growth was observed, +: suitable substrate, -: no uptake or microalgae growth was observed with the substrat 
Table 3. Overview of studies carried out with raw fermentation effluents.

\begin{tabular}{|c|c|c|c|c|c|c|c|c|c|c|c|c|}
\hline \multicolumn{2}{|c|}{ Fermentation process } & \multirow[b]{2}{*}{ Effluent treatments } & \multicolumn{8}{|c|}{ Microalgae growth } & \multirow[b]{2}{*}{ Studies/ Comments } & \multirow[t]{2}{*}{ Reference } \\
\hline & $\begin{array}{c}\text { Mixed or pure } \\
\text { culture } \\
\text { Substrate } \\
\end{array}$ & & $\begin{array}{l}\text { Metabolites concentration } \\
\qquad\left(\mathrm{g} \cdot \mathrm{L}^{-1}\right)\end{array}$ & $A: B^{a}$ & $\begin{array}{l}\mathrm{H} / \\
\mathrm{M}\end{array}$ & $\begin{array}{c}\mathrm{pH} \\
\text { control }\end{array}$ & species & $\mathrm{S} / \mathrm{X}$ & $\mathrm{Y}_{\mathrm{b} / \mathrm{S}}$ & $\begin{array}{l}\text { Xprod } \\
\left(\mathrm{g} . \mathrm{L}^{-1}\right) \\
\mathrm{c}\end{array}$ & & \\
\hline \multirow{5}{*}{ 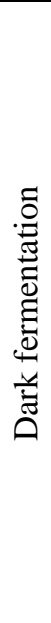 } & $\begin{array}{l}\text { Pure (Clostridium) } \\
\text { Glucose, xylose }\end{array}$ & $\begin{array}{l}\text { Dilution: } 1 / 4 \\
\text { Sterile }\end{array}$ & $\begin{array}{l}\text { Acetate }: 0.3 \\
\text { Butyrate }: 0.8 \\
\text { Formate }: 0.04 \\
\text { Lactate }: 0.05\end{array}$ & 0.4 & $\begin{array}{l}\mathrm{H} \\
\mathrm{M}\end{array}$ & N.M. & C. vulgaris & 4.8 & $\begin{array}{l}0.38 \\
0.80\end{array}$ & $\begin{array}{l}0.45 \\
0.7\end{array}$ & $\begin{array}{l}\text { Partial butyrate } \\
\text { exhaustion } \\
\mathrm{S} / \mathrm{X} \text {, light intensity, } \\
\mathrm{CO}_{2} \text { sparging } \\
\end{array}$ & {$[15]$} \\
\hline & $\begin{array}{l}\text { Pure (Clostridium) } \\
\text { sucrose }\end{array}$ & $\begin{array}{l}\text { Dilution: } 1 / 4 \\
\text { Sterile }\end{array}$ & $\begin{array}{l}\text { Acetate }: 0.5 \\
\text { Butyrate : } 1.13 \\
\text { Lactate: } 0.78\end{array}$ & 0.4 & $\mathrm{M}$ & No & C. vulgaris & 9.6 & 0.09 & 0.21 & $\begin{array}{l}\text { Lactate was not } \\
\text { consumed } \\
\text { S/X }\end{array}$ & {$[14]$} \\
\hline & \begin{tabular}{|l|} 
Mixed \\
Glucose
\end{tabular} & $\begin{array}{l}\text { Not diluted } \\
\text { Sterile and unsterile }\end{array}$ & $\begin{array}{l}\text { Acetate }: 0.7 \\
\text { Butyrate } 1.25\end{array}$ & 0.6 & $\mathrm{H}$ & Buffer & \begin{tabular}{|l|} 
C. \\
sorokiniana
\end{tabular} & 97 & 0.16 & 0.31 & $\begin{array}{l}\text { Microalgae } \\
\text { consumed acetate. }\end{array}$ & {$[67]$} \\
\hline & $\begin{array}{l}\text { Mixed } \\
\text { Food waste } \\
\end{array}$ & Dilution: $7 / 10$ & $\begin{array}{l}\text { Acetate }: 1.13 \\
\text { Butyrate }: 0.83 \\
\text { Propionate: } 0.24 \\
\end{array}$ & 1.4 & $\mathrm{M}$ & N.M. & Mixed algae & 15 & 0.41 & 1.22 & $\begin{array}{l}\text { Bacterial growth } \\
\text { was not monitored. }\end{array}$ & {$[18]$} \\
\hline & $\begin{array}{l}\text { Pure } \\
\text { (Ethanoligenens) } \\
\text { Glucose }\end{array}$ & $\begin{array}{l}\text { Not diluted } \\
\text { Sterile }\end{array}$ & $\begin{array}{l}\text { Acetate: } 3 \\
\text { Butyrate: } 0.15 \\
\text { Ethanol: } 2.7\end{array}$ & 20 & $\mathrm{H}$ & N.M. & $\begin{array}{l}\text { Scenedesmus } \\
\text { sp. }\end{array}$ & 58 & 0.34 & 1.88 & $\begin{array}{l}\text { Ethanol was not } \\
\text { consumed. }\end{array}$ & {$[7]$} \\
\hline \multirow{4}{*}{ 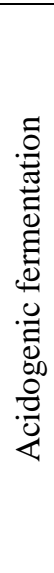 } & $\begin{array}{l}\text { Mixed } \\
\text { Soybean } \\
\text { processing } \\
\text { wastewater } \\
\end{array}$ & $\begin{array}{l}\text { Dilution: } 1 / 2.7 \\
\text { Sterile }\end{array}$ & $\begin{array}{l}\text { Acetate: } 0.67 \\
\text { Butyrate: } 0.25 \\
\text { Propionate: } 0.44 \\
\text { Others: }<0.11 \\
\end{array}$ & 2.7 & $\mathrm{M}$ & N.M. & $\begin{array}{l}\text { C. } \\
\text { pyrenoidosa }\end{array}$ & 4.9 & 1.23 & 1.85 & $\begin{array}{l}\text { VFAs represented } \\
70 \% \text { of initial } \\
\text { COD. }\end{array}$ & {$[12]$} \\
\hline & $\begin{array}{l}\text { Mixed } \\
\text { Secondary sludge }\end{array}$ & $\begin{array}{l}\text { Not diluted } \\
\text { Sterile }\end{array}$ & $\begin{array}{l}\text { Acetate: } 4.5 \\
\text { Butyrate: } 1 \\
\text { Propionate: } 1.3 \\
\text { Iso-valerate: } 1.1 \\
\text { Iso-butyrate \& valerate: }<0.8\end{array}$ & 4.5 & $\mathrm{M}$ & Yes & C. vulgaris & 58 & 0.47 & 4.08 & $\begin{array}{l}\text { VFAs represented } \\
75 \% \text { of initial } \\
\text { COD. }\end{array}$ & {$[17]$} \\
\hline & $\begin{array}{l}\text { Mixed } \\
\text { Swine manure }\end{array}$ & $\begin{array}{l}\text { Dilution: } 1 / 20 \\
\text { Sterile }^{\mathrm{d}} \text { and unsterile }\end{array}$ & $\begin{array}{l}\text { Acetate: } 0.30 \\
\text { Butyrate:0.03 } \\
\text { Propionate: } 0.24\end{array}$ & 10 & $\mathrm{M}$ & N.M. & Chlorella $\mathrm{sp}$. & 2.2 & \begin{tabular}{|l|}
0.79 \\
$\mathrm{c}$ \\
0.79 \\
\end{tabular} & 0.35 & $\begin{array}{l}\text { Bacterial growth } \\
\text { was not monitored. }\end{array}$ & {$[58]$} \\
\hline & \begin{tabular}{|l|} 
Mixed \\
Swine manure
\end{tabular} & Dilution: $1 / 8$ & $\begin{array}{l}\text { Total: } 1.5-1.8 \mathrm{~g} / \mathrm{L} \\
\text { (composition N.M.) }\end{array}$ & & $\mathrm{M}$ & Yes $^{\mathrm{e}}$ & Chlorella $\mathrm{sp}$. & & $0.37 \mathrm{f}$ & & $\begin{array}{l}\text { Bacterial growth } \\
\text { was not monitored. }\end{array}$ & {$[9]$} \\
\hline
\end{tabular}

The mentioned experiment was carried out in Fed-batch mode. $\mathrm{pH}$ was maintained between $7-8$ at steady state, ${ }^{\mathrm{f}}$. biomass yield could not be calculated in $\mathrm{g}$ g-1 with the data available and was calculated as g per $\mathrm{g}$ of DCO;N.M.: Not Mentioned in the study; S/X: substrate:biomass ratio 